\title{
Sequestering Biomass for Natural, Efficient, and Low-Cost Direct Air Capture of Carbon Dioxide
}

\author{
Jeffrey A. Amelse a,b and Paul K. Behrens ${ }^{\mathrm{c}}$
}

a) Universidade de Aveiro, Departamento de Química, CICECO, 3810-193 Aveiro, Portugal, JAmelse@UA.Pt

b) Independent Contributor, Batavia, IL USA, AmelseJeff@Gmail.com

c) Independent Contribuitor and Chemical Industry Consultant, Greenfield, IN, USA PKBConsult2@Gmail.com

Abstract - Many corporations and governments aspire to become Net Zero Carbon Dioxide by 2030-2050. Achieving Net Zero $\mathrm{CO}_{2}$ requires understanding where energy is produced and consumed, the magnitude of $\mathrm{CO}_{2}$ generation, and the Carbon Cycle. It is unreasonable to assume that fossil fuel can be completely replaced, and thus, atmospheric $\mathrm{CO}_{2}$ will continue to accumulate. Many prior proposed solutions focus on reducing future $\mathrm{CO}_{2}$ emissions from continued use of fossil fuels. Examination of these technologies exposes their limitations and shows that none offer a complete solution. Direct Capture technologies are needed to reduce $\mathrm{CO}_{2}$ already in the air. However, some of those already proposed would lead to a very high cost of Carbon Capture, Use, and Storage (CCUS). Biofuels can help achieve reduction goals. However, two of the six carbons in sugar fermented to bioethanol produce $\mathrm{CO}_{2}$ per the stoichiometry of the reaction. Four carbons go to ethanol, which go back to the atmosphere upon burning in an engine. Thus, without CCUS, which most current bioethanol plants do not practice, bioethanol would at best be sustainable. The only way to permanently remove $\mathrm{CO}_{2}$ already in the atmosphere is to break the Carbon Cycle by growing biomass from atmospheric $\mathrm{CO}_{2}$ and permanently sequestering that biomass carbon. Permanent sequestration can be achieved in landfills modified to discourage biomass decomposition to $\mathrm{CO}_{2}$ and methane. Sequestration of biomass carbon is proposed as a simple and natural means of Direct Capture. Tree leaves are proposed as a good source of biomass for this purpose. Left unsequestered, leaves decompose with a short Carbon Cycle time constant releasing $\mathrm{CO}_{2}$ back to the atmosphere. Leaves represent a substantial fraction of the total biomass generated by a tree when integrated over a tree's lifetime. High yield crops, such as switchgrass would also be a good source of biomass. The cost for growing switchgrass and sequestering it in a landfill is estimated to be on the order of $\$ 120 / \mathrm{mt} \mathrm{CO}_{2}$ for a conservative yield of 3.5 tons/acre and may be reduced to as low as $\$ 88 / \mathrm{mt} \mathrm{CO}_{2}$ if the development of high yield switchgrass is successful. This compares to an estimated cost of CCUS from the Steam Reforming of Methane to produce hydrogen of about $\$ 190 / \mathrm{mt}$. Thus, sequestration of biomass is shown to be a natural, carbon efficient, and low-cost method of Direct Capture.
Keywords - Carbon Dioxide, Net Zero, Sequestration, Biomass, Direct Capture, Global Warming.

\section{Introduction}

Carbon dioxide is the dominant greenhouse gas component leading to Global Warming. If man does nothing to intervene, atmospheric $\mathrm{CO}_{2}$ levels are projected to more than double to over 900 ppmv by 2100 [1]. Many corporations and governments have set goals of Net Zero $\mathrm{CO}_{2} . \mathrm{A} \mathrm{CO}_{2}$ material balance indicates: In - Out $=$ Net Rate of Accumulation. In order to achieve a Net Zero $\mathrm{CO}_{2}, \mathrm{CO}_{2}$ removal must equal $\mathrm{CO}_{2}$ generation. Preferably $\mathrm{CO}_{2}$ removal from the atmosphere exceeds generation to reduce the level of $\mathrm{CO}_{2}$ already in the atmosphere, which is already leading to Global Warming. Many new technologies for confronting $\mathrm{CO}_{2}$ accumulation and fuels decarbonization are under rapid development. These include technologies for renewable energy, biofuels, hydrogen production from fossil fuels with Carbon Capture, Use, and Storage (CCUS), and $\mathrm{CO}_{2}$ removal and sequestration from large point source industrial furnaces. Most focus on reducing future $\mathrm{CO}_{2}$ emissions. The advantages and challenges of some of these technologies were reviewed in an unpublished preprint [2].

Methods for removing $\mathrm{CO}_{2}$ already in the air are known as Direct Capture methods. In one direct air capture technology, being developed by companies such as Climeworks and Carbon Engineering, large fans blow air through an adsorbent or absorbent $[3,4]$. The $\mathrm{CO}_{2}$ must then be released by adding heat, followed by $\mathrm{CO}_{2}$ compression to liquify to allow it to be transported for industrial uses or permanent storage underground. There are numerous issues with this technology that put current estimates of the cost of recovered $\mathrm{CO}_{2}$ as high as $\$ 800 /$ tonne [5]. First, an enormous amount of air with 400 ppm $\mathrm{CO}_{2}$ must be moved the adsorbent to remove even a small amount of $\mathrm{CO}_{2}$. The fans have high capital and operating cost. There is the cost of heat required to release the $\mathrm{CO}_{2}$, and high capital and operating cost to compress, transport and store the captured $\mathrm{CO}_{2}$.

One issue for decarbonization by $\mathrm{CO}_{2}$ recovery is what to do with the recovered $\mathrm{CO}_{2} . \quad \mathrm{CO}_{2}$ has value for certain markets, 
such as carbonation of beverages and tertiary oil recovery. However, the markets where the $\mathrm{CO}_{2}$ has value are small compared to the current 36 giga tonnes/yr (Gt/yr) generated. Beyond those markets, recovered $\mathrm{CO}_{2}$ has negative value.

A 2005 Energy Information Authority (EIA) report estimated that the markets where $\mathrm{CO}_{2}$ has value extend out to about 700 million metric tonnes per year (MMt/yr) [6]. That compares to about $36 \mathrm{Gt} / \mathrm{yr}$ total generation. EIA identified geological formations having a total storage capacity of about $3800 \mathrm{Gt}$ $\mathrm{CO}_{2}$. The mean cost for storage in deep saline aquifers was estimated to be about $\$ 12.5 / \mathrm{t} \mathrm{CO}_{2}$ in 2005 , which is $\$ 17 / \mathrm{t} \mathrm{CO}_{2}$ in 2020 when escalated using the US Consumer Price Index (CPI).

There is a lot of focus on the use of hydrocarbons to produce hydrogen as a clean burning $\mathrm{CO}_{2}$-free fuel. However, the carbon must go somewhere. The carbon ends up as $\mathrm{CO}_{2}$ that must be recovered and disposed.

Hydrogen can be produced by steam reforming or partial oxidation of hydrocarbons. For natural gas, the preferred route is steam reforming (Steam Reforming of Methane (SRM)). In a first step, methane is reacted with steam at high temperature to form a synthesis gas $\left(\mathrm{CO}+\mathrm{H}_{2}\right)$ :

$$
\mathrm{CH}_{4}+\mathrm{H}_{2} \mathrm{O}=\mathrm{CO}+3 \mathrm{H}_{2}
$$

This reaction is strongly endothermic: $\Delta \mathrm{Hr}=206 \mathrm{~kJ} / \mathrm{mol}$

In a second step, the $\mathrm{CO}$ is reacted with more water via the water-gas shift reaction to form more hydrogen plus $\mathrm{CO}_{2}$ :

$\mathrm{CO}+\mathrm{H}_{2} \mathrm{O}=\mathrm{H}_{2}+\mathrm{CO}_{2}$

This reaction is mildly exothermic: $\Delta \mathrm{Hr}=-41 \mathrm{~kJ} / \mathrm{mol}$.

The net reaction is:

$\mathrm{CH}_{4}+2 \mathrm{H}_{2} \mathrm{O}=4 \mathrm{H}_{2}+\mathrm{CO}_{2}$

The overall reaction remains strongly endothermic: $\Delta \mathrm{Hr}=165 \mathrm{~kJ} / \mathrm{mol}$.

Thus, a large amount of heat must be put into the process. That heat generally goes into the reformer process furnace by burning additional natural gas. Of course, the furnace flue gas contains $\mathrm{CO}_{2}$. For hydrogen from steam reforming to be a " $\mathrm{CO}_{2}$-free" fuel, both the $\mathrm{CO}_{2}$ produced by the reactions and $\mathrm{CO}_{2}$ in the flue gas must be recovered and sequestered.

For low molecular weight hydrocarbons with low $\mathrm{C}: \mathrm{H}$ ratio, steam reforming is preferred. For hydrocarbons with high $\mathrm{C}: \mathrm{H}$ ratios, such as coal, or even elemental carbon, partial oxidation is preferred, as shown in Equation 4 for carbon:

$$
\mathrm{C}+1 / 2 \mathrm{O}_{2} \rightarrow \mathrm{CO}
$$

Theoretically, any hydrocarbon can be steam reformed or undergo partial oxidation and the $\mathrm{CO}$ reacted with water to produce hydrogen and $\mathrm{CO}_{2}$ via Reaction 2 .
The steam reforming or partial oxidation of biomass can produce "Green Hydrogen." The use of biomass to produce hydrogen represents an alternate Direct Capture technology, since the biomass carbon is produced from atmospheric $\mathrm{CO}_{2}$ via photosynthesis. Thus, "Green Hydrogen" production from biomass with CCUS represents one form of Direct Capture.

An understanding of the Carbon Cycle indicates that the only way to remove $\mathrm{CO}_{2}$ already in the air is to grow biomass from atmospheric $\mathrm{CO}_{2}$ and then permanently remove that biomass carbon from the Carbon Cycle. Steam reforming or partial oxidation of biomass, followed by water-gas shift and $\mathrm{CO}_{2}$ capture and storage is one way. However, it is expensive, since it requires high capital, energy and other operating and fixed costs for the hydrogen plant, and CCUS. The cost of $\mathrm{CO}_{2}$ capture and sequestration from an SRM hydrogen plant will be calculated in this manuscript.

In this manuscript, we propose a simple and more natural method of Direct Capture. Furthermore, this method will be shown to have a lower cost of CCUS than an SRM hydrogen plant.

In the proposed method, biomass is grown from atmospheric $\mathrm{CO}_{2}$ via photosynthesis and the biomass carbon is sequestered (permanently removed from the Carbon Cycle) by secure burial in landfills modified to discourage biomass degradation. Thus, this is Carbon Sequestration as opposed to $\mathrm{CO}_{2}$ Sequestration.

Tree leaves had been proposed as a good source of biomass for sequestration [2]. Leaves have a short Carbon Cycle time constant on the order of one year and they are renewable every year. Leaves are shown to represent a significant portion of the total biomass generated by a tree when integrated over the life of a tree. Left unsequestered, leaves decompose and release their carbon as $\mathrm{CO}_{2}$ back to the atmosphere to complete their Carbon Cycle. Sequestering leaves as opposed to tree trunks and branches would have certain advantages. Sequestering leaves would leave the underlying forests undisturbed. Furthermore, trees have a very long Carbon Cycle time constant on the order of decades to centuries, as opposed to leaves which are renewed every year and have a short decomposition time constant on the order of a year.

Of course, other sources of biomass should be considered, such as crops or grasses grown for the purpose of carbon sequestration, or municipal waste. The cost to grow and sequester the carbon in switchgrass in a landfill will be used as a proxy to estimate the cost of $\mathrm{CO}_{2}$ capture for the proposed biomass carbon sequestration, and that cost will be compared to the cost for $\mathrm{CO}_{2}$ capture and storage from an SRM hydrogen plant.

In fact, growing and sequestering switchgrass for the purpose of direct $\mathrm{CO}_{2}$ capture may have certain advantages over gathering leaves. Growing switchgrass is very analogous to growing hay which is well established farm technology practiced on a massive scale. The cost of harvesting hay is well known [7]. The cost of harvesting switchgrass should be very similar. 


\section{The energy scene}

Before discussing the proposal, it is helpful to examine the current energy scene, i.e., what fuels are used, where they are used, and to examine the current world energy consumption by fuel source, and the amount of $\mathrm{CO}_{2}$ currently being generated each year to understand the magnitude of the problem and show that prior proposed technologies will fall short of the goal of achieving Net Zero $\mathrm{CO}_{2}$ by 2050.

The US Energy Information Authority (EIA) provides a database that tracks primary energy production and disposition for the US, and other world regions [8]. BP provides its yearly Statistical Energy Review [9].

Fig. 1 shows the US 2016 (pre-pandemic) primary energy source and sector in which the energy is used [10]. The three largest sources are petroleum (37\%), natural gas (29\%), and coal $(15 \%)$. In 2016 only about $10 \%$ of primary energy came from renewables.

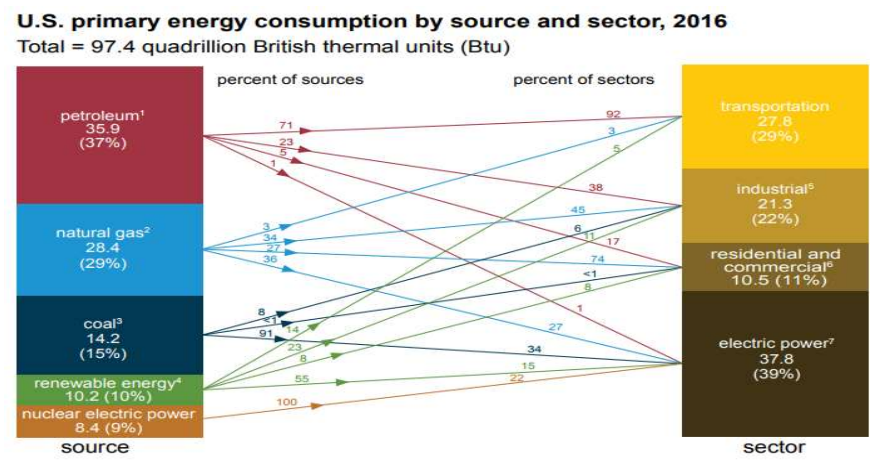

Fig. 1. US Primary energy consumption by source and sector, 2016 Source: EIA (2017) [10]. All rights reserved.

The numbers on the left of the lines connecting sources to usage sectors show the percentage of a source that goes to a corresponding sector. The major sectors are transportation $(29 \%)$, industry (22\%), and electric power (39\%). Industrial use accounts for $22 \%$ and residential and commercial accounts for $11 \%$.

The numbers on the right of Fig. 1 show the percentage of energy used in a sector that comes from the corresponding source. Thus, $71 \%$ of petroleum goes to the transportation sector with most of the balance (23\%) going to industry, and only minor amounts to residential and commercial and electric power sectors. Natural gas usage is split almost evenly amongst industrial, residential and commercial, and electric power, with very little to transportation. Coal and nuclear are almost exclusively used to generate power.

In 2016, $\mathrm{CO}_{2}$ emissions were $36 \mathrm{Gt}$ [10]. The world has a huge $\mathrm{CO}_{2}$ problem that is going to take a variety of huge solutions to solve. Fig. 1 shows the US energy demand. World energy demand is different. In particular, coal represents a much higher fraction of energy demand in China. China dominates world energy demand. Asia and Oceania account for almost half of total energy demand., Thus, it is not surprising that coal and coke (a heavy-end solid refinery byproduct that can be substituted for coal) represent about $44 \%$ of total energy demand. Petroleum and other liquids represent about $36 \%$, and natural gas about 20\%. Coal usage in China exceeds that in the rest of the world combined, as shown in Fig. 2. Thus, while coal usage is declining worldwide, it will continue to play a major role in China, and a solution is needed for the $\mathrm{CO}_{2}$ coming from coal.

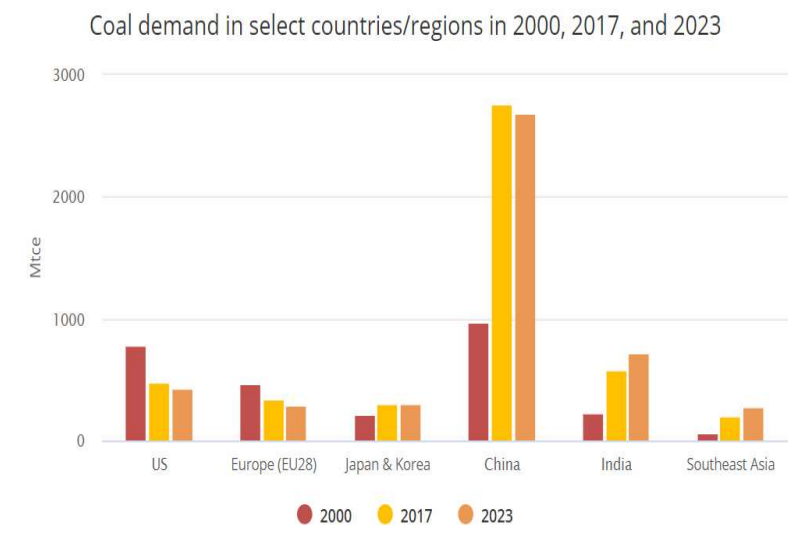

Fig. 2. Coal demand in select countries/regions

Data Source: (EIA, 2017). All Rights Reserved. [10]

The EIA provides a projection for the shift in all energy sources for electricity production (Fig. 3), and further granularity for the sources of renewable energy for electricity production out to 2050 (Fig. 4) [11]. Coal is expected to decline from $24 \%$ to $13 \%$, and nuclear is expected to decline from $24 \%$ to $12 \%$. Renewable energy is projected to double but will still be under $40 \%$ of the total energy sources. -

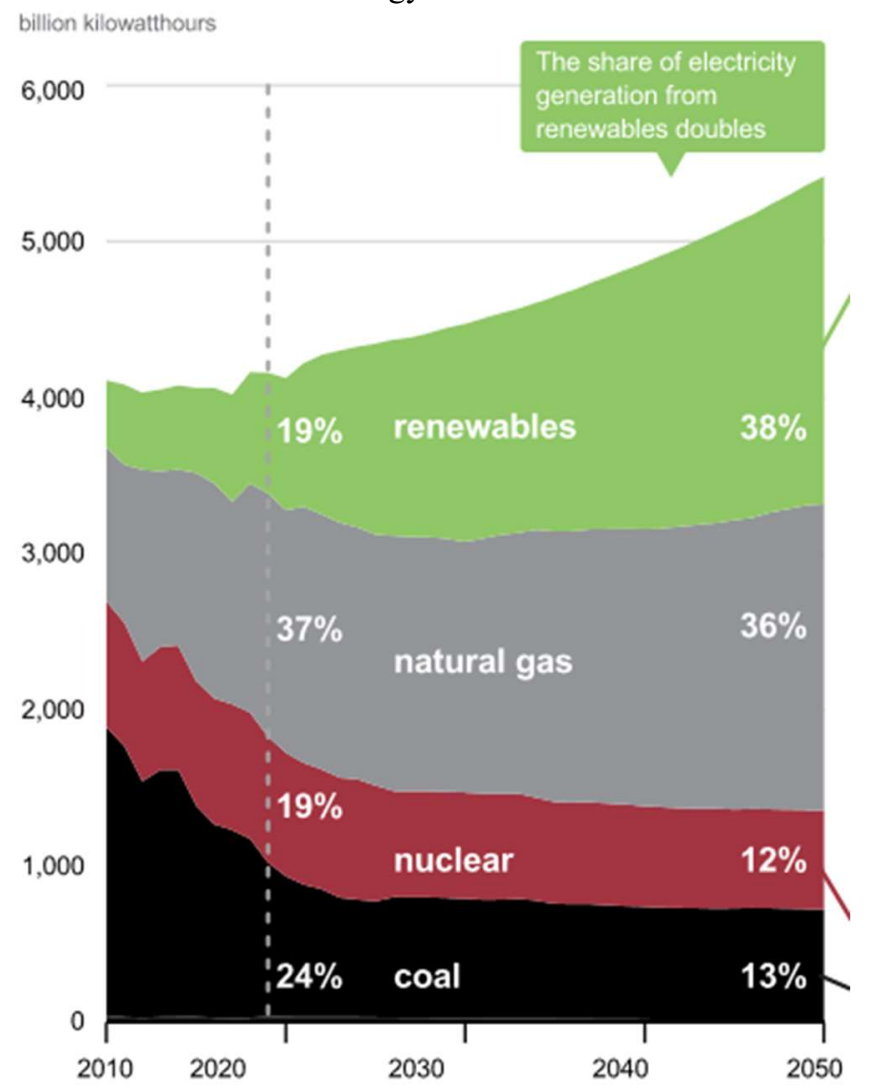

Fig. 3. Shift in all sources of energy for electricity. Source: (EIA, 2020). All Rights Reserved. [11] 


\section{U.S. renewable electricity generation is the fastest-growing electricity resource throughout the projection period.}
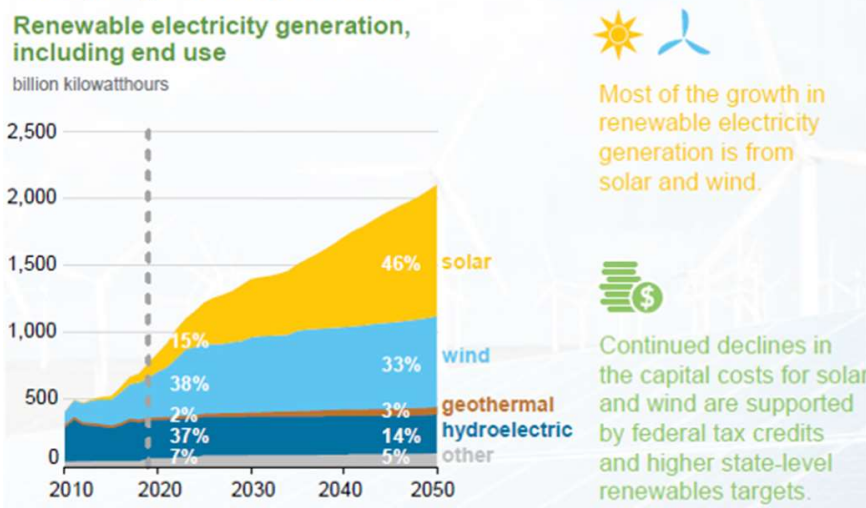

Fig. 4. Shift in source of renewable energy for electricity. Source: (EIA, 2020). All Rights Reserved. [11]

The absolute amount of electricity from wind is projected to double. Solar is projected to increase by a factor of 9 . One question to ask is: Is that a reasonable projection? Natural gas has become cheap and abundant in the US after the advent of fracking. The EIA projects that the fraction of electricity coming from natural gas remains about constant near 36 to $37 \%$ out to 2050. This is still a very significant percentage and a significant percentage of $\mathrm{CO}_{2}$ production. Thus, a means to sequester $\mathrm{CO}_{2}$ during the production of electricity from natural gas is needed, especially if the projected increase of electricity from solar falls short.

The energy for transportation is distributed between passenger cars, long haul trucks, aviation, and rail. US passenger cars are currently fueled primarily by gasoline. Thus, in the US, gasoline represents about $47 \%$ of refined products [12]. Distillates represent about 30\%, with LPG (7\%) and Other Petroleum Liquids (chemical feedstocks, etc.) representing the balance. US distillate fuels represent about $20 \%$ of US refined products with about $67 \%$ of distillates used for on-highway diesel mainly for long haul trucks). Jet fuel is about $8 \%$ of US refined products [13]. Diesel cars are more popular in Europe. Thus, for example in Germany, distillate fuel oils represent about $46 \%$-and gasoline only about $18 \%$ of refined products [12].

US gasoline currently contains about $10 \mathrm{vol} \%$ bioethanol. Thus, bioethanol represents only a trivial amount of total US energy consumption $(29 \% \times 47 \% \times 10 \%=1.4 \%)$, and that comes at great economic and social cost. Currently about $40 \%$ of the US corn crop is devoted to fuel ethanol [14]. Furthermore, the stoichiometry of the fermentation reaction converts only 4 of the 6 carbons in glucose sugar formed by hydrolysis of corn starch to ethanol and 2 carbons to $\mathrm{CO}_{2}$ :

$$
\mathrm{C}_{6} \mathrm{H}_{12} \mathrm{O}_{6} \rightarrow 2 \mathrm{C}_{2} \mathrm{H}_{5} \mathrm{OH}+2 \mathrm{CO}_{2}
$$

Most US ethanol plants currently vent the $\mathrm{CO}_{2}$ to atmosphere. The 4 out of 6 sugar carbons that go to bioethanol represent renewable carbon that will displace future fossil fuels from continued gasoline production. They will not reduce $\mathrm{CO}_{2}$ already in the atmosphere. Only the 2 of 6 carbons that go to $\mathrm{CO}_{2}$ during fermentation will represent Direct Capture $\mathrm{CO}_{2}$, and only if bioethanol plants are fitted with CCUS. Bioethanol is not break-even sustainable, when the energy used to produce the corn and within the process is considered. Water removal from the ethanol fermentation beer is energy intensive [2].

Bioethanol from cellulosic biomass has been a long-term goal due to potentially cheap feedstock and no diversion of food to fuel. A Sandia study indicated that 70 billion gallons of cellulosic ethanol should be "possible" by 2030 [15]. However, only about $15 \mathrm{MM}$ gal were produced in 2018 [16]. The reality is that continued economic and technical challenges remain.

Biodiesel penetration into the total diesel market is even lower than bioethanol penetration at about $6 \%$ of diesel for onhighway use (only about $4 \%$ of total US distillate oils), and that consumes about $30 \%$ of US soybean oil [17,18]. It also consumes corn oil in a ratio of about 27 liters corn oil to about 73 liters soybean oil $[17,18]$. Corn oil is the most valuable product from corn wet mill plants, and thus is an expensive feedstock.

The future for zero $\mathrm{CO}_{2}$ emission passenger cars is electric vehicles. Powering them by renewable electricity would make them truly net zero $\mathrm{CO}_{2}$ emitters (not counting $\mathrm{CO}_{2}$ related to their manufacture and battery production). The reality is that electric vehicles represented only $1.5 \%$ of new vehicle sales in Q1 2019 [19]. Also, recall that EIA projections are that natural gas will still account for $36 \%$ of electricity generation in 2050 needed to power them (Fig. 3). Also, electric passenger cars represent only a portion of energy for transportation, which accounts for only about $30 \%$ of total energy consumption. Long haul trucks, rail and aviation represent a significant fraction of transportation energy. Currently there are no practical electric drives for those modes.

Clearly, other solutions are needed to achieve net $\mathrm{CO}_{2}$ emission goals by 2050 .

\section{Understanding the Carbon Cycle}

The Carbon Cycle is misunderstood by many. There are those who believe planting more trees will lead to a reduction in atmospheric $\mathrm{CO}_{2}$. It is true that deforestation and burning of trees leads to a temporary large release of $\mathrm{CO}_{2}$, and reforestation leads to temporary reduction of atmospheric $\mathrm{CO}_{2}$. However, if one follows trees through their entire life cycle, trees are sustainable. They pull $\mathrm{CO}_{2}$ from the air during their life. However, in unmanaged forests, tree biomass eventually decomposes and a tree's stored carbon is released to the atmosphere as $\mathrm{CO}_{2}$. Trees lose their leaves every year, which decompose and release their stored carbon back to the atmosphere on a time scale of approximately one year. At the end of their life, trees die, decompose, and release the carbon stored in their trunks and branches. Thus, trees are sustainable. Over their entire life and death cycle, planting trees will not lead to a net reduction in $\mathrm{CO}_{2}$ that is already in the atmosphere.

Plants get all of their carbon for their growth from $\mathrm{CO}_{2}$ in the atmosphere via photosynthesis, forming carbohydrates [20]. 
The photosynthesis reaction can be represented crudely by the reaction:

$$
6 \mathrm{CO}_{2}+6 \mathrm{H}_{2} \mathrm{O}+\text { sunlight } \rightarrow \mathrm{C}_{6} \mathrm{H}_{12} \mathrm{O}_{6}+6 \mathrm{O}_{2}
$$

The simplest formula representation of carbohydrates is $\mathrm{CH}_{2} \mathrm{O}$, Thus the amount of $\mathrm{CO}_{2}$ plants pull from the atmosphere an be calculated roughly from plant mass using the ratio of molecular weights: $\left.\left(44.01 \mathrm{gm} / \mathrm{mol} \mathrm{CO}_{2}\right) / 30.03 \mathrm{gm} \mathrm{CH}_{2} \mathrm{O}\right)$.

Plant matter is fed to animals and plants and animals are fed to humans. Animals and humans respire the bulk of the carbon in their food as $\mathrm{CO}_{2}$ when they exhale. Animals and humans grow and thus serve as temporary storage vessels for some of the carbon. However, plants, animals, and humans eventually die and decompose and release their carbon back to the atmosphere as $\mathrm{CO}_{2}$, completing their part of the Carbon Cycle. Plant matter left on the ground decomposes via the action of worms, fungi, and bacteria. They feed on the decomposing biomass, and respire $\mathrm{CO}_{2}$, and thus, play an important role in the Carbon Cycle. Normally there is no net buildup of carbon in the soil. Soil carbon generally reaches a steady state carbon level of 1-4 weight percent (wt\%) [21]. Yes, depending on farming practices, there can be a small increase or decrease of plant matter carbon in the soil. However, it is small and limited. If there were a large net movement of carbon to the soil, mountains would spring up in the US corn belt, and that is clearly not the case.

While plants receive all of their carbon from the atmosphere, they draw water as a source of hydrogen, nitrogen, phosphorous and other nutrients such as potassium from the soil. The enzyme that catalyzes photosynthesis contains both nitrogen and phosphorous [21]. In the natural Carbon Cycle, dead plant material returned to the soil feeds the worms, bacteria, and fungi that decompose it releasing the needed N, P, K, and other nutrients back into the soil. That is part of the Carbon Cycle. Intensive farming requires artificial fertilizer to provide some of the nutrients removed with the farm products.

Thus, the normal Carbon Cycle is sustainable. Over time, there is no net movement of $\mathrm{CO}_{2}$ to the atmosphere and no net movement of carbon into the ground. The only way to remove $\mathrm{CO}_{2}$ already in the atmosphere is to break the cycle. Biomass must be grown from $\mathrm{CO}_{2}$ in the atmosphere and the biomass itself must be sequestered (Carbon sequestration, not $\mathrm{CO}_{2}$ sequestration).

\section{Sequestration of biomass carbon}

As noted earlier, renewable energy, biofuels without CCUS, and $\mathrm{CO}_{2}$ sequestration will reduce future $\mathrm{CO}_{2}$ from continued use of fossil fuels entering the atmosphere. However, doing it on a scale needed to meet current and future energy demands is daunting. Furthermore, these are not a complete solution to achieve Net Zero $\mathrm{CO}_{2}$, so other solutions are needed.

Per an understanding of the Carbon Cycle, the only way to remove $\mathrm{CO}_{2}$ already in the atmosphere is to grow biomass and remove that biomass from the Carbon Cycle by permanent sequestration.
If the biomass in the entire corn plant from the $40 \%$ of the US corn crop that is now devoted to bioethanol production were sequestered and removed from the Carbon Cycle, instead of just the starch in the corn kernels going to bioethanol, that would be the equivalent of removing $407 \mathrm{MMt} / \mathrm{yr}$ of $\mathrm{CO}_{2}$ per year compared to the $36 \mathrm{Gt} / \mathrm{yr} \mathrm{CO}_{2}$ generated [2]. Something else is needed to achieve Net Zero $\mathrm{CO}_{2}$ to the atmosphere.

In this manuscript, secure burial of biomass from other sources, including municipal and yard waste and biomass generated in forests (tree leaves and wood) or from growing high yield crops, such as switchgrass is proposed as a supplemental solution. Secure burial means permanent burial with provisions taken to prevent decomposition and release of the $\mathrm{CO}_{2}$ to the atmosphere. Thoughts on how to achieve secure sequestration with minimal or no $\mathrm{CO}_{2}$ to the atmosphere are provided in the next sections.

Permanent sequestration of municipal and yard waste in permanent landfills would remove that carbon from the Carbon Cycle and would remove $\mathrm{CO}_{2}$ already in the atmosphere that would feed the growth of the organic materials in those waste sources. In addition, it would remove $\mathrm{CO}_{2}$ going to the atmosphere from refinery and petrochemical processes used to produce plastics, if plastics are included in the waste to be buried. Systems are in place to collect yard and municipal waste in most large cities in the US, and elsewhere in the world, so part of the cost is already sunk.

Most municipal yard waste is buried in landfills. Some municipal waste is now burned to generate renewable power. One issue for that application is that even after separation of recyclables, average municipal waste still contains about $20 \%$ non-organics (glass, metal, etc.), as shown in Fig. 5 that must be separated before the organics can be burned [22]. Secure landfilling to sequester all of the waste would not require this stringent and costly separation.

How big of a difference could secure sequestration of municipal and yard waste make? The US EPA provides statistics on municipal and yard waste generated, and how much is ultimately landfilled [22]. In 2017, the total amount of US municipal and yard waste generated was $267.8 \mathrm{MM}$ tons. Some is separated and recycled, and some is currently burned to generate renewable power, leaving the amount landfilled at 139.6 MM tons, with composition provided in Fig. 5. The organic component was 112.5 MM tons. That corresponds to 149.6 MM metric tonnes of $\mathrm{CO}_{2}$ if allowed to completely decompose. This compares to the $6480 \mathrm{MM}$ tons per year $\mathrm{CO}_{2}$ generated in the US and is far short of the $36 \mathrm{Gt} / \mathrm{yr} \mathrm{CO}_{2}$ currently being generated worldwide. Participation by other countries would help, but clearly not enough to solve the daunting $\mathrm{CO}_{2}$ problem.

Other biomass is needed for pulling $\mathrm{CO}_{2}$ from the atmosphere: trees, both tree leaves and/or wood, and high yield crops. The USDA has provided allometric equations for urban tree growth parameters for many species and at numerous locations in the US [23]. The growth equations have been programmed into EXCEL files which are available in SI.1 (Supplemental Input). Dry leaf biomass is calculated for most species and regions where data are available. 
Total MSW Landfill by Material, 2017

139.6 million tons

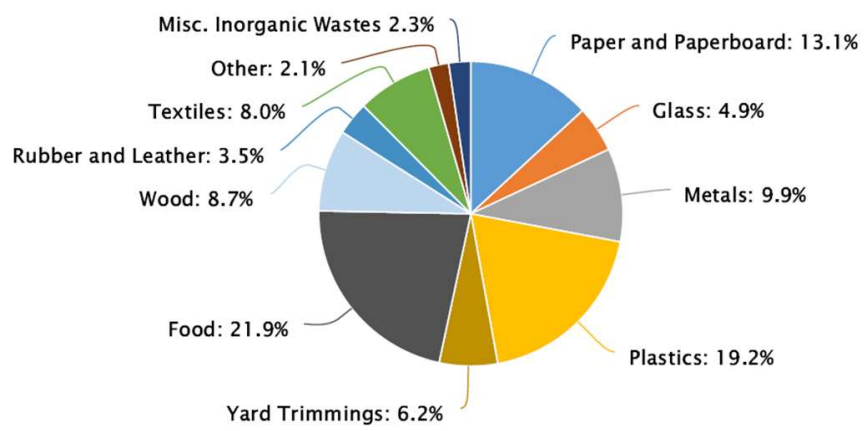

Fig. 5. US 2017 Municipal and Yard Waste Landfilled Source: (EPA, 2020) [22].

Dry leaf biomass for some species of maple trees at various locations in the US are shown in in Fig. 6, as an example. Data for other tree species are provided in SI.1. Dry leaf biomass can be over $100 \mathrm{~kg} / \mathrm{yr}$ for some of the maples and over $400 \mathrm{~kg} / \mathrm{yr}$ for some of the oaks depending on location and age.

Leaves currently fall to the ground and decompose every year. Assuming a conservative average of $50 \mathrm{~kg} / \mathrm{yr}$ dry weight of leaves per tree, if forests were managed, the leaves gathered and permanently securely buried, this would be the equivalent of over $(50 \mathrm{~kg} / \mathrm{yr}$ dry wgt $) *\left(44.01 \mathrm{gm} \mathrm{CO} 2 / 30.03 \mathrm{gm} \mathrm{CH}_{2} \mathrm{O}\right)=$ $73 \mathrm{~kg} / \mathrm{yr} \mathrm{CO} 2$ removed from the atmosphere per tree every year.

According to the latest estimate, there are over 3 trillion trees in the world [24-25]. However, only about $30 \%$ of the trees are deciduous. At $73 \mathrm{~kg} / \mathrm{yr}$-tree $\mathrm{CO}_{2}$ equivalent per tree that is the potential to remove $66 \mathrm{Gt} / \mathrm{yr} \mathrm{CO}_{2}$, compared to $36 \mathrm{Gt} / \mathrm{yr} \mathrm{CO} 2$ generated each year. Thus, theoretically sequestering tree leaves could provide a complete solution to our $\mathrm{CO}_{2}$ fossil fuel problem. The potential is enormous but sequestering all of those leaves would be daunting.

One secondary issue for sequestering biomass will be the replacement of $\mathrm{P}, \mathrm{N}$, and $\mathrm{K}$ nutrients needed for photosynthesis. This can be done via chemical fertilization. This will generate $\mathrm{CO} 2$, but this can be compensated by additional biomass sequestration.

Mature tree wood weights can be several metric tonnes per tree, as shown in Fig. 7. Removal and secure burial of tree wood would help. However, there are several issues. First, tree trunks and tree branches have a much longer Carbon Cycle time constant (on the order of decades or centuries) compared to leaves (on the order of one year). However, it is not needed. Harvesting leaves would suffice. While the mass of leaves dropped in a particular year is much less than that of the tree trunk and branches, leaf mass becomes appreciable relative to the latter when integrated over the life of the tree. Also, harvesting leaves alone would not disrupt the forest itself, and leaves are renewed every year. It is best to leave the wood for its current uses (construction, furniture, etc.). Managing new forest plantings should be considered with access provided for leaf collection. In Brazil, secure burial of bagasse should be considered instead of burning it to produce power, which releases the bagasse $\mathrm{CO}_{2}$ back to the atmosphere, albeit renewable $\mathrm{CO}_{2}$. The bagasse is already at the ethanol plant. It could be buried in a site nearby to minimize transportation costs. Sequestration of other biomass, such as underbrush should also be considered.

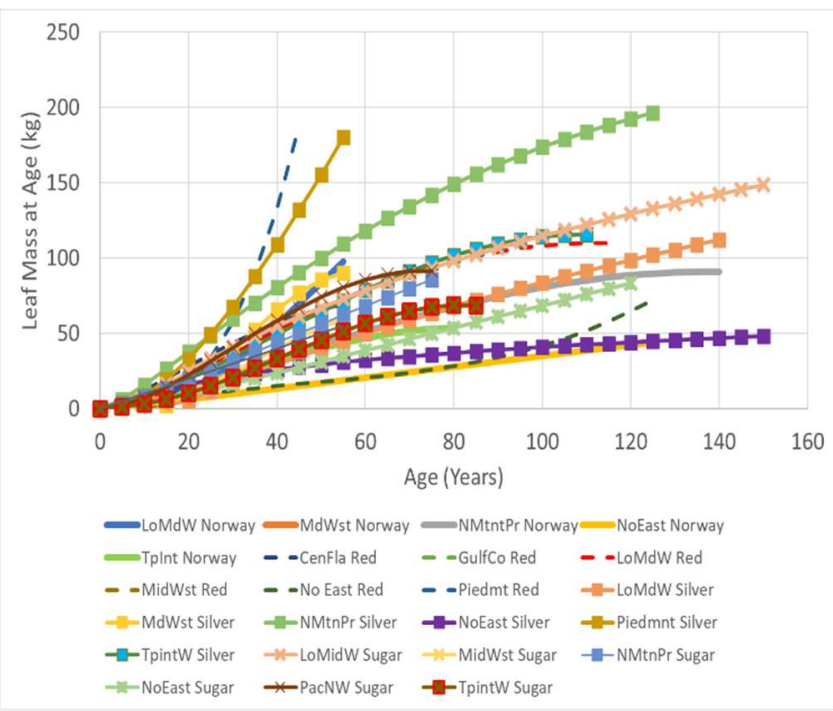

Fig. 6. Yearly dry leaf biomass generation by some maple tree species in various regions of the US Source: McPherson, van Doorn, and Peper (2016) [23].

The US regions include: LoNdWst=Lower Midwest; MidWst=Midwest; NMtnPr=North: No East $=$ North East; CenFla $=$ Central Florida; $\mathrm{GulfCo}=$ Gulf Coast; Piedmt $=$ South .

Figs. 6 and 7 represent calculations from the regression equations for the allometric tree growth equations provided by McPherson, van Doorn, and Peper (2016) [23]. Twelve equation forms were used for different species and different locations, including quadratic, cubic, quartic, exponential and $\ln (\ln )$. Some are not well behaved for extrapolation. Thus, they were not extrapolated beyond the limits provided. However, even within the limits, some projections showed declines in mass with age, and thus, were truncated at the point where that happened.

Fig. 8 provides calculated cumulative leaf biomass as a percentage of total tree biomass generated (including tree trunk and branches) up to a given tree age. Note that the calculations show some erratic behavior from the combining of two illbehaved correlations in some cases. Considerable scatter is observed depending on species and location. Nonetheless, this figure shows that the cumulative leaf mass can be a significant fraction of the total tree biomass generated over the life of the tree. In certain cases, the regressed percentage of leaf biomass exceeds $50 \%$ to over $70 \%$ of the total biomass generated over the life of the tree.

\section{Modified landfills for biomass carbon sequestration}

Permanent sequestration of municipal waste and plant biomass will require rethinking how landfills are designed. 
Currently, landfills are designed to allow or even encourage some decomposition of the waste to minimize volume. Permanent sequestration requires discouraging waste degradation in landfills.
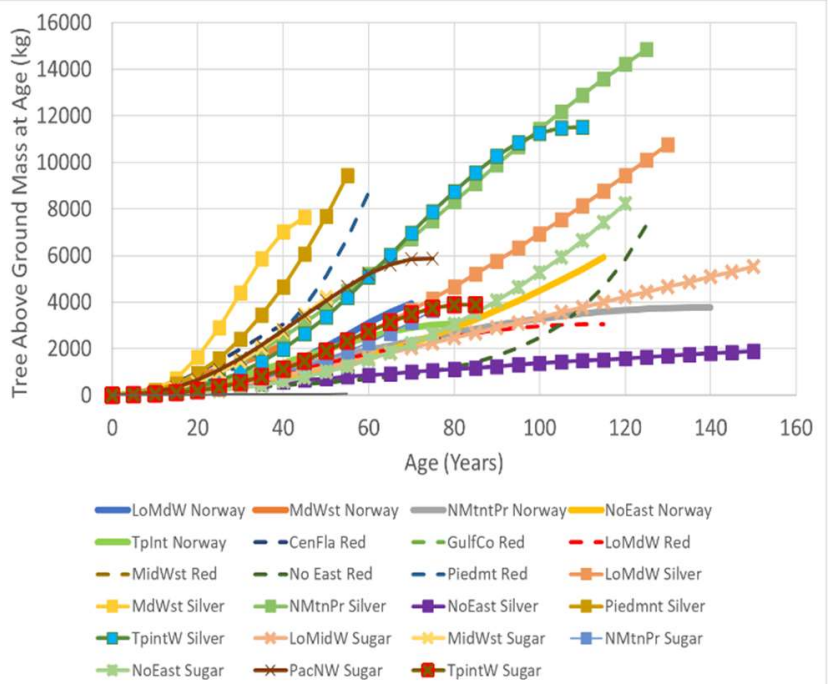

Fig. 7. Above ground biomass for some Maple tree species in various regions of the US.

Source: McPherson, van Doorn, and Peper (2016) [23].

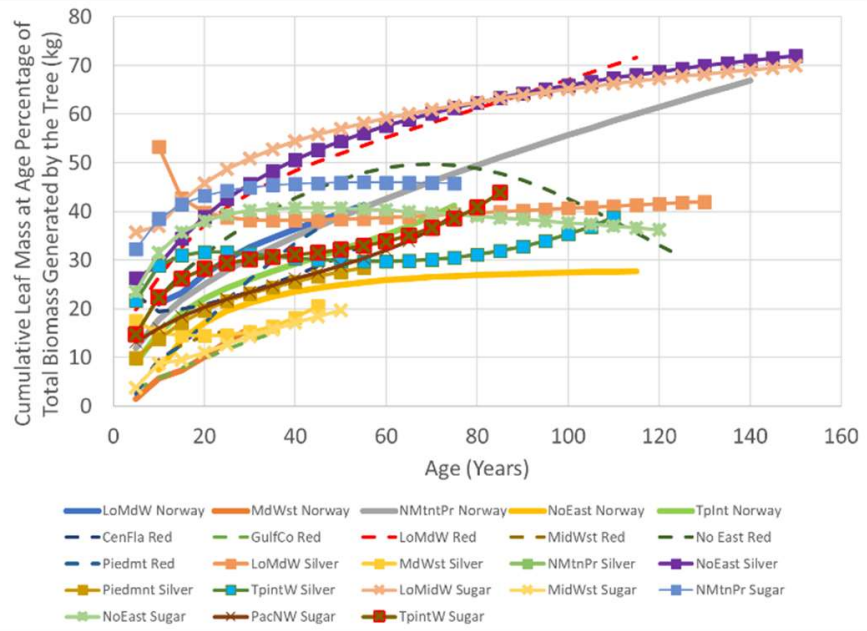

Fig. 8. Calculated cumulative leaf biomass as a percentage of total biomass generated over the life of various species of Maple trees at various locations in the US.

Municipal waste is buried in landfills, where a portion slowly decomposes. It undergoes a combination of aerobic and anaerobic decomposition to produce a biogas. Modern landfills undergo several distinct stages [26-28].

\section{Phase I (Initial Adjustment)}

During the first phase of decomposition, aerobic bacteria that require oxygen to live consume oxygen while breaking down the complex carbohydrates, proteins, and lipids that comprise organic waste. The primary byproduct of this process is carbon dioxide. Nitrogen content is high at the beginning of this phase, due to nitrogen in the air that supplies the oxygen for aerobic decomposition. Nitrogen content continuously declines as the landfill moves through the phases. Phase I continues until available oxygen is depleted. Phase I decomposition can last for days or months, depending on how much oxygen is present when the waste is disposed in the landfill, which can vary depending on how compacted the waste was when it was buried.

\section{Phase II (Acid Phase)}

Phase II decomposition starts after the oxygen in the landfill has been depleted. Anaerobic bacteria then convert compounds created by aerobic bacteria into acetic, lactic, and formic acids and alcohols such as methanol and ethanol. The landfill becomes highly acidic. With the presence of moisture, the acids cause certain nutrients to dissolve, making nitrogen and phosphorus nutrients available to the bacteria present during this phase. The biogas comprises mainly carbon dioxide and hydrogen during this phase.

\section{Phase III (Methane Formation)}

Phase III decomposition starts when anaerobic bacteria consume the organic acids produced in Phase II and form acetates. This process causes the landfill to become a more neutral environment in which methane-producing bacteria establish themselves. Methane- and acid-producing bacteria have a mutually beneficial relationship. Acid producing bacteria create compounds for the methanogenic bacteria to consume. Methanogenic bacteria consume the carbon dioxide and acetate, too much of which would be toxic to the acidproducing bacteria.

\section{Phase IV (Stable Phase)}

Phase IV decomposition begins when both the composition and production rates of landfill gas remain relatively constant. Phase IV landfill gas usually contains approximately $45 \%$ to $60 \%$ methane by volume, $40 \%$ to $60 \%$ carbon dioxide.

\section{Phase V (Mature Phase)}

Landfills eventually enter a mature phase. The rate of microbiological activity slows during this phase as the supply of nutrients and/or moisture limits the chemical reactions, e.g. as bioavailable phosphorus becomes increasingly scarce. $\mathrm{CH}_{4}$ production almost completely disappears. Thus, complete decomposition may take hundreds to thousands or even millions of years.

The anaerobic decomposition phase produces a biogas. On average, about half of the volumetric concentration of landfill gas is methane and slightly less than half is $\mathrm{CO}_{2}$. Methane has a climate change potential that is 25 times more powerful than $\mathrm{CO}_{2}$. Thus, anaerobic decomposition is to be discouraged in the landfills proposed for biomass sequestration.

Landfills are now designed with underground collection systems, and the gas is typically routed to flares, and burned as a renewable fuel. Thus, the carbon in the gas is converted to $\mathrm{CO}_{2}$ which goes back to the atmosphere. Some landfills now route the gas to boilers for power generation (renewable power generation), or other uses.

How can landfills be redesigned to minimize or eliminate biomass degradation? By understanding the degradation chemistry, there are opportunities to interrupt the process at each phase. Phase I degradation could be minimized by minimizing the landfill working volume as material is moved 
to the non-working volume which is moving towards later phases. The working volume may be covered by tarps at night or covered by foam. This is already being done in some landfills. Nitrogen blanketing could eliminate the oxygen needed for aerobic decomposition.

Simplified equations for anaerobic degradation of cellulose are:

$\left(\mathrm{C}_{6} \mathrm{H}_{10} \mathrm{O}_{5}\right)_{\mathrm{n}}+\mathrm{n} \mathrm{H}_{2} \mathrm{O} \rightarrow \mathrm{n} \mathrm{C}_{6} \mathrm{H}_{12} \mathrm{O}_{6}$

Hydrolysis (depolymerization) of cellulose to release sugars.

$n \mathrm{C}_{6} \mathrm{H}_{12} \mathrm{O}_{6} \rightarrow 3 \mathrm{n} \mathrm{CH}_{4}+3 \mathrm{n} \mathrm{CO}_{2}$

Anaerobic digestion to form methane and $\mathrm{CO}_{2}$.

Water is needed to first depolymerize the cellulose to release the sugars that serve as food for the anaerobic bacteria. Thus, one key to reducing or eliminating anaerobic degradation is to keep water out, i.e., preferably to dry the biomass in drying fields, and sealing the landfill as it moves beyond Phase I.

Another way to discourage anaerobic decomposition is to exploit known inhibitors of anaerobic bacteria [29]. These include among others, $\mathrm{pH}$ adjustment, high concentration of alkali or alkaline earth metals, etc.

Municipal waste used to be accumulated in open piles. Modern landfills with daily, intermediate, and final covers only began in the 1940s and accelerated in the 1960s and 1970s. None of the modern landfills have gone through their full life cycle, which can take hundreds to thousands or even millions of years. The evidence is the huge mounds that are left by modern landfills that have had their final earthen caps installed and are then abandoned.

Can secure permanent sequestration of biomass carbon really be achieved? The answer is: Yes, it can. Can some leakage be tolerated during the five stages? The answer is: Yes. However, it will increase the amount of material that needs to be sequestered to compensate for these losses. Some biogas can be allowed and collected and burned to generate renewable power to displace fossil fuels as is currently done at many landfill sites.

Thus, secure permanent landfills are envisioned that are modifications of current landfills. These landfills may also be located near the source of biomass to minimize transportation cost.

\section{Are Steps to Prevent Degradation in a Landfill Absolutely Necessary?}

Steps to reduce or eliminate biomass degradation are desirable but will add cost. Are they absolutely necessary?

Coscuner, et al. [30] modeled landfill gas generation in a landfill in Bahrain. using the US Environmental Protection Agency's Landfill Gas Emission Model software [31]. The data in Tables 1 and 2 of that manuscript allow the calculation of the fraction of the fraction of decomposable waste that is predicted to decompose after 120 years following landfill closure. That landfill opened in 1987 and closed in 2019. The total amount of waste deposited was about 23,000 tonnes. The MSW (Municipal Solid Waste) was comprised of $35.2 \%$ food waste, $11.6 \%$ paper and cardboard, $4.1 \%$ textiles, and $18.4 \%$ plastics.
The model requires input of $\mathrm{DOC}=$ Degradable Organic Carbon.

$$
\mathrm{DOC}=0.4(\mathrm{~A})+0.17(\mathrm{~B})+0.15(\mathrm{C})+0.3(\mathrm{D})
$$

where A is the fraction of MSW that is paper and textile wastes, B is the fraction of garden/park wastes or another nonfood organic degradable waste, $\mathrm{C}$ is the fraction of food waste and $\mathrm{D}$ is the fraction of wood and straw wastes.

For the case of the Bahrain landfill, $\mathrm{A}=0.157, \mathrm{~B}=0.028$, $\mathrm{C}=0.352$, and $\mathrm{D}=0.018$, i.e., the total fraction of decomposable waste $=0.555$. The fraction of plastic film and other plastics in the MSW was 0.184 . Per the US EPA model this material does not decompose, as it should not, per the stoichiometric equations for anaerobic decomposition (Equations 9 and 10), because petrochemical plastics such as PET, or polyolefins do not contain oxygen atoms.

The EPA model predicts an exponential decline in biogas generation (methane and $\mathrm{CO}_{2}$ ) for 120 years after landfill closure. Fig. 9 shows that if the model were extrapolated to 500 years, the percentage of decomposable material that would have decomposed reaches an asymptote of about 18\%. The calculations are provided in SI.2. Thus, if one were to take no additional action to prevent biomass degradation, over $80 \%$ of the decomposable biomass would never decompose, thus proving the premise of this manuscript that secure landfilling of biomass is a viable way to pull $\mathrm{CO}_{2}$ from the atmosphere to offset $\mathrm{CO}_{2}$ from continued use of fossil fuels.

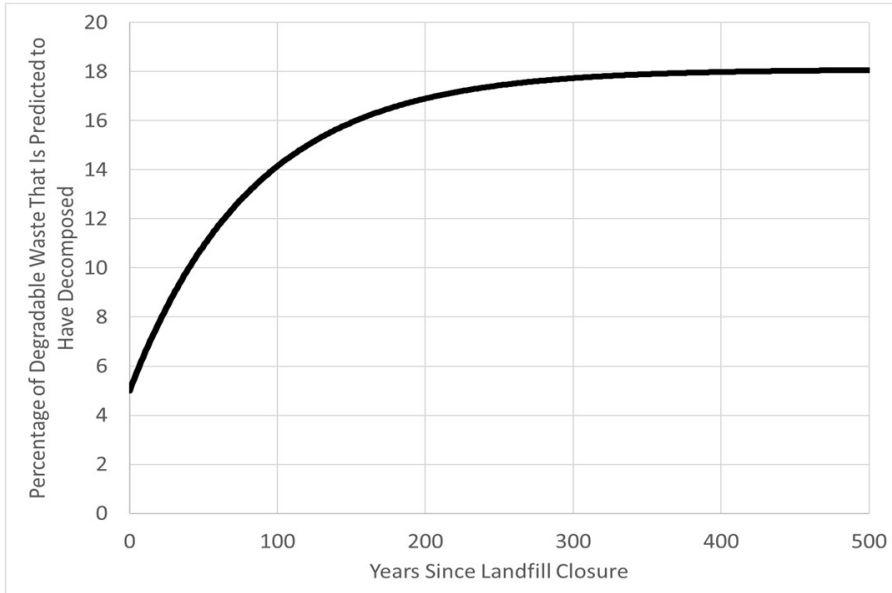

Fig. 9. Percentage of degradable biomass that would decompose calculated by extrapolating the US EPA Landfill Gas Emissions Model (LandGEM) for a landfill in Bahrain [30-31]

\section{The Cost of CCUS for a SRM Hydrogen Plant}

There is much interest and many recent papers and webinars related to hydrogen production, because hydrogen is a carbonfree fuel. The steam reforming of methane (SRM) is technology that has been practiced for almost 100 years as a means of producing hydrogen for refineries and chemical plants.

In this section, the cost of $\mathrm{CO}_{2}$ sequestration from an SRM 
hydrogen plant will be considered as a basis for comparison to the proposed method.

A schematic of a typical SRM hydrogen plant is provided in Fig. 10.

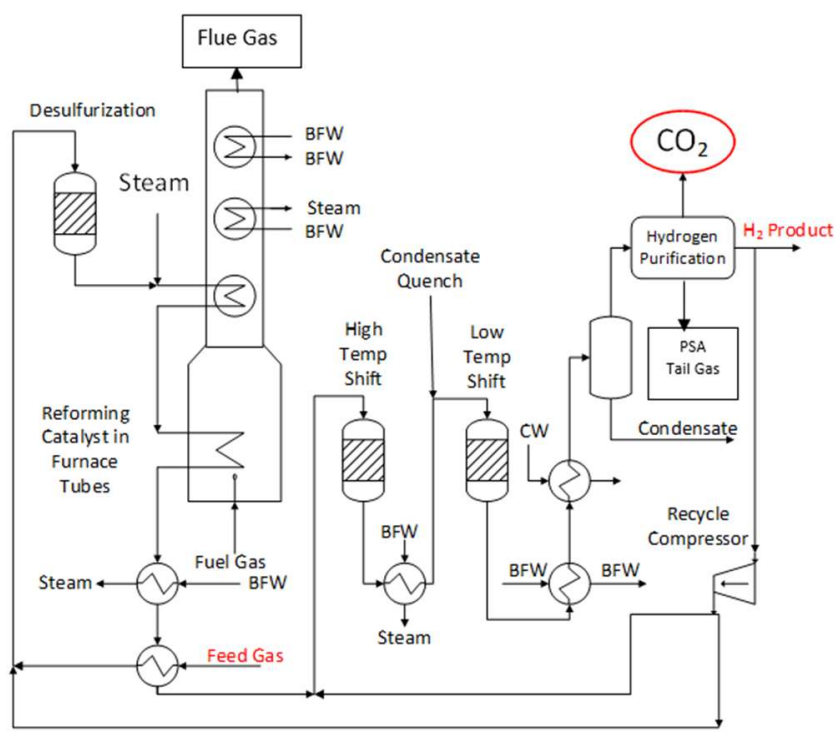

Fig. 10. Process Flow Diagram for a Hydrogen Plant $\mathrm{BFW}=$ Boiler Feed Water; $\mathrm{CW}=$ Cooling Water

Feed gas is preheated and pretreated to remove sulfur. The pretreated gas is mixed with steam (and some recycled hydrogen product) and reformed over a catalyst at high temperature. For small hydrogen plants, the reforming "reactor" is catalyst packed right into furnace tubes. The feed is first preheated by heat exchange with hot flue gas. Heat is recovered from the hot flue gas by generating steam. The hot effluent from the steam reforming reactor is cooled and passed to water-gas shift reactors. Equilibrium conversion to $\mathrm{CO}_{2}$ and $\mathrm{H}_{2}$ in the water-gas shift reactors is favored by low temperature. Watergas shift conversion is limited by thermodynamics, which favors higher conversion at lower temperatures. Thus, the shift may be done in two steps. A first high temperature shift reactor is used to provide faster reaction kinetics. A second low temperature shift reactor is used as a trim reactor to provide high conversion.

The hydrogen atoms in the methane are converted to water. The water is manly removed by cooling and separation in a condensate drum.

$\mathrm{CO}_{2}$ separation and hydrogen purification and separation is shown as a block (Hydrogen Purification) in Fig. 10. Within that block, hydrogen separation and purification is commonly done by a pressure swing adsorption (PSA) unit. The PSA unit produces the purified hydrogen product and a PSA tail gas that contains unreacted $\mathrm{CH}_{4}$, unrecovered $\mathrm{H}_{2}$, unconverted $\mathrm{CO}$, and $\mathrm{CO}_{2}$. The $\mathrm{CH}_{4}, \mathrm{H}_{2}$, and $\mathrm{CO}$ give the tail gas a heating value. This gas is burned in the reformer furnace. However, since the reforming reaction is so endothermic, additional natural gas is needed.

$\mathrm{CO}_{2}$ is typically removed from the PSA tail gas by absorption in an amine solution followed by $\mathrm{CO}_{2}$ removal from the rich amine solution in a stripper distillation column. $\mathrm{CO}_{2}$ stripping is energy intensive. The stripped $\mathrm{CO}_{2}$ is compressed to liquify for export.

Note that steam is generated in multiple places in the process. That steam can be used to turn turbines to generate electricity in a combined cycle power plant, in which the hydrogen product can be burned to produce more steam and more power, or it can be exported for use in a refinery or chemical plant or elsewhere (the basis for a hydrogen economy). In a hydrogen plant dedicated to $\mathrm{H}_{2}$ production for a refinery or chemical plant, net steam is produced, that must find a home. Receiving value for export steam is very important for the economics of these units.

A block flow diagram for an SRM hydrogen plant with CCUS is shown in Fig, 11, which shows where $\mathrm{CO}_{2}$ must be recovered to make this hydrogen " $\mathrm{CO}_{2}$-free," This figure assumes that $\mathrm{CO}_{2}$ produced in the process is recovered from the PSA tail gas. It could be recovered ahead of the PSA unit, but this generally leads to lower recovery and higher cost, since the $\mathrm{CO}_{2}$ is more dilute ahead of the PSA.

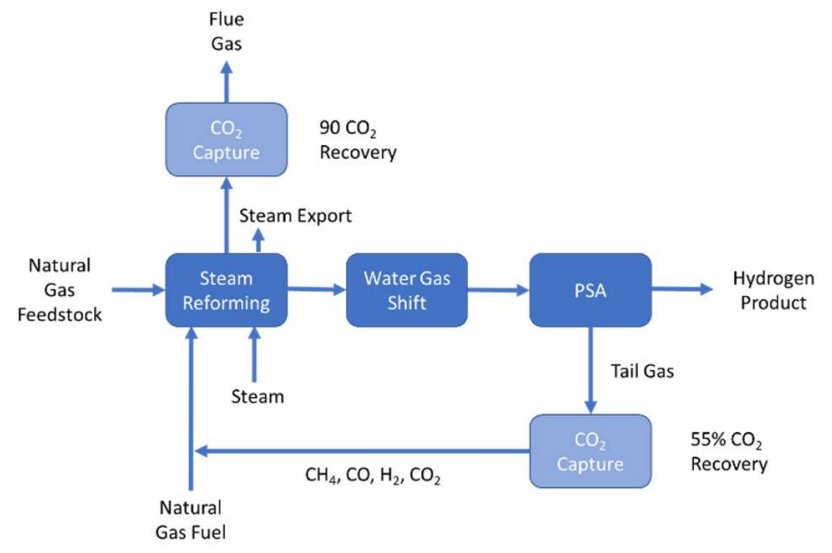

Fig. 11. SRM Hydrogen Plant Block Flow Diagram

IEA provided estimates for $\mathrm{H}_{2}$ production cost for an SRM with and without CCUS for various world regions [32]. $\mathrm{H}_{2}$ cost is broken down into natural gas cost, CAPEX and OPEX. These costs came from an engineering study performed by Foster-Wheeler [33] for a large 100,000 Nm3/hr SRM $\mathrm{H}_{2}$ plant. For reference, the world's five largest single train SRM plants range from $151,000 \mathrm{Nm}^{3} / \mathrm{hr}$ to $240,000 \mathrm{Nm}^{3} / \mathrm{hr}$.

The modeled plant produces $100,000 \mathrm{Nm}^{3} / \mathrm{hr} \mathrm{H} 2=9.0 \mathrm{t} / \mathrm{hr}$ $\mathrm{H}_{2}$, and $23.7 \mathrm{t} / \mathrm{hr} \mathrm{CO}_{2}$ (combined furnace flue gas and PSA tail gas). The IEA incremental CAPEX (with CCUS vs. no CCUS) is $\$ 0.26 / \mathrm{kg} \mathrm{H}_{2}$ and the incremental OPEX is $\$ 0.24 / \mathrm{mt} \mathrm{H}_{2}$, which correspond to $\$ 99 / \mathrm{mt} \quad \mathrm{CO}_{2}$ and $\$ 91 / \mathrm{t} \quad \mathrm{CO}_{2}$ respectively, assuming $100 \% \mathrm{CO} 2$ recovery. Thus, total cost for CCUS is $\$ 190 / \mathrm{CO}_{2}$, or higher depending on $\mathrm{CO}_{2}$ recovery efficiency.

\section{The Cost of CCUS for Biomass Sequestration in a Landfill}

The cost of CCUS for biomass sequestration will be comprised of two components: 1) the cost of harvesting leaves, or the cost of growing and harvesting cultivated biomass such as switchgrass; and 2) the cost of landfilling. 
Growing and landfilling switchgrass will be considered first. Farm-Energy (2019) estimated the cost of producing switchgrass in the US Upper Midwest at $\$ 65 /$ short ton dry matter $(\$ 72 / \mathrm{mt})$ [34]. This assumes a switchgrass yield of 3.5 ton/acre. New varieties of switchgrass are being developed that could increase yield to 6 ton/acre, which would lower production cost to about $\$ 38 /$ ton $(\$ 42 / \mathrm{mt})$.

Bagchi provided a cost estimate for landfilling municipal waste at $\$ 20 /$ ton [35]. This estimate in the third edition of his book is the same as in the first edition published in 1990. In a private conversation, he suggested inflating that cost by the Consumer Price Index, which when converting to metric units brings the cost in 2020 to $\$ 46 / \mathrm{mt}$.

Thus, the total cost for growing and sequestering switchgrass in a landfill would be $\$ 118 / \mathrm{mt}$ at a conservative yield of 3.5 ton/acre, or as low as $\$ 88 / \mathrm{mt}$ for a yield of 6 ton/acre. Thus, growing and sequestering switchgrass would be a low-cost Direct Capture option.

The cost for harvesting and bailing hay is well known [7], and thus the cost of producing switchgrass should be accurate. The cost for harvesting tree leaves would have more uncertainty. Harvesting leaves from established forests would have no growing costs. However, harvesting costs would be expected to be higher for leaves due to lower compacted density. The density of hay is about $150-250 \mathrm{~kg} / \mathrm{m} 3$ [36], compared to a density of about $113 \mathrm{~kg} / \mathrm{m} 3$ for compacted leaves. The latter value is from a private email dated April 27, 2021 from the Commissioner of Streets and Sanitation for the city of Batavia, Illinois.

How much $\mathrm{CO}_{2}$ capture potential does growing and sequestering switchgrass provide? The following numbers use the ratio of $\mathrm{CO}_{2} / \mathrm{CH}_{2} \mathrm{O} \mathrm{MW}$ of $44.0 / 30.03$, a conservative switchgrass yield of 3.5 tonne/acre, and assumes $80 \%$ permanent capture in an unmodified landfill. Corn is the primary feed grain, accounting for more than $95 \%$ of total feed grains in the US. In 2019, greater than $90 \mathrm{MM}$ acres of corn were planted in the US [37]. If the $40 \%$ of that crop devoted to bioethanol were replanted with switchgrass and sequestered, the $\mathrm{CO}_{2}$ capture potential is $148 \mathrm{MMt} / \mathrm{yr}$. In 2019, 89.1 MM acres of soybeans were planted in the US [38]. If half of that land were devoted to switchgrass, that $\mathrm{CO}_{2}$ capture potential would be $183 \mathrm{MM}$ tonnes. In addition, range and pastureland accounts of $27 \%$ of total land in the contiguous US, or $528 \mathrm{MM}$ acres [39]. If half of that land were devoted to switchgrass, the $\mathrm{CO}_{2}$ capture potential would be $1.1 \mathrm{Gt} / \mathrm{yr}$. If high yield switchgrass providing a yield of 7 tonnes/acres were to be developed, these numbers would double. Of course, this is just in the US. The world potential is enormous. Combined with energy conservation, renewable energy, $\mathrm{CO}_{2}$ sequestration from large point sources, and leaf and other biomass sequestration, and other carbon capture innovations, Net Zero $\mathrm{CO}_{2}$ could be within reach.

\section{Final Comments}

Here are some final comments regarding the proposal of permanent biomass sequestration as a means of removing $\mathrm{CO}_{2}$ already in the atmosphere (Direct Capture).

- Theoretically can it achieve Net Zero $\mathrm{CO}_{2}$ ? Yes, there are enough leaves that it can on its own independent of other technologies.

- Is it technically sound? Yes. Landfills can be designed to prevent biomass degradation to $\mathrm{CO}_{2}$ and/or methane. In fact, encouraging degradation may be a more difficult problem as evidenced by the huge mounds left by traditional landfills. Also, as shown above, very little degradation of biomass occurs without modifications to further reduce degradation.

- Is it actionable? Yes. It could be put into practice in the timeframe required (before 2035-2050).

- Are there secondary issues? Yes: 1) Designing new managed forests with leaf collection in mind; 2) Soil nutrient replacement, etc.; and 3) Designing secure leaf landfills with no or minimal decomposition and leakage. However, it is thought that these issues can be addressed by gathering the right group of people (experts in forestry, soil chemistry, landfill management).

- The potential for carbon capture via tree leaf collection and growing and sequestering switchgrass is enormous as shown in Sections 4 and 8.

- Is it still a daunting problem? Yes. To achieve Net Zero $\mathrm{CO}_{2}$ for the current $36 \mathrm{Gt} / \mathrm{yr}$ of $\mathrm{CO}_{2}$ using this technique alone would require sequestering an enormous amount of material. Of course, this would be reduced, perhaps in half, by energy conservation, renewable energy, $\mathrm{CO}_{2}$ sequestration, other carbon capture innovations, etc. Even at incomplete implementation, it can play a role in reducing net $\mathrm{CO}_{2}$ to the atmosphere.

- Can any of the other proposed technologies achieve Net Zero $\mathrm{CO}_{2}$ on their own? No.

- How would biomass landfill projects be funded? Carbon credits are currently being traded. The business model for this proposal would be: Corporations would invest in the landfills and leaf or biomass growth and collection. Farmers would grow high yield crops for Direct Capture carbon sequestration. Carbon credits would be sold to recover investments.

\section{Conclusions}

Carbon dioxide from fossil fuels is the main culprit of Global Warming. The problem is massive; $36 \mathrm{Gt} / \mathrm{yr} \mathrm{CO}_{2}$ are being released into the atmosphere. Finding a solution requires an understanding of where energy is produced and consumed and a proper understanding of the Carbon Cycle. While renewable energy is growing rapidly, it remains a very small part of overall energy. Other solutions are needed.

Bioethanol and biodiesel remain a small part of energy for transportation, which itself is less than $30 \%$ of overall energy consumed. Corn ethanol is at best be sustainable, but not when energy for production is considered. Two of the six carbons of glucose are converted to $\mathrm{CO}_{2}$ during fermentation, which most facilities release to the atmosphere before any useful work is done in an engine. Cellulosic ethanol promises cheap feedstock, but still faces a number of technical and economic challenges. This has slowed implementation. The reality is that only about 
$15 \mathrm{MM}$ gallons of cellulosic were produced in 2018 compared to $16,868 \mathrm{MM}$ gal of corn ethanol.

$\mathrm{CO}_{2}$ sequestration can target $\mathrm{CO}_{2}$ produced in large industrial furnaces, including those used to generate electric power. Industrial and power plant furnaces account for about half of $\mathrm{CO}_{2}$ generated. This is significant, but $\mathrm{CO}_{2}$ sequestration will not be a complete solution.

There is much recent attention on the steam reforming of natural gas to produce hydrogen. SRM can indeed produce clean burning " $\mathrm{CO}_{2}$-free" hydrogen fuel, if CCUS is added. Coal can undergo partial oxidation to $\mathrm{CO}$, followed by shifting $\mathrm{CO}$ by reaction with $\mathrm{H}_{2} \mathrm{O}$ to $\mathrm{CO}_{2}$ and $\mathrm{H}_{2}$ via the water-gas shift reaction. With CCUS, coal has the potential to be converted to a " $\mathrm{CO}_{2}$-free" fuel. One issue for $\mathrm{CO}_{2}$ capture is what to do with the $\mathrm{CO}_{2}$. The markets where $\mathrm{CO}_{2}$ has positive value are limited. Beyond that, $\mathrm{CO}_{2}$ must be buried underground in spent oil or gas wells or underground saline formations.

Renewable energy, biofuels without CCUS, and $\mathrm{CO}_{2}$ sequestration from industrial furnaces can displace future $\mathrm{CO}_{2}$ from continued use of fossil fuels. The only way to reduce $\mathrm{CO}_{2}$ already in the atmosphere is to grow biomass from atmospheric $\mathrm{CO}_{2}$ via photosynthesis and permanently sequester that biomass. Rather than spending capital and energy to convert that biomass to biofuels, which is both energy inefficient and an inefficient use of biomass carbon, permanent sequestration of biomass carbon from tree leaves, crops, and municipal and yard waste is proposed. Permanent sequestration can take place via landfills modified to prevent aerobic decomposition to $\mathrm{CO}_{2}$ or anaerobic decomposition to $\mathrm{CO}_{2}$ and methane. Theoretically, sequestration of only a fraction of the world's tree leaves can bring the world to Net Zero $\mathrm{CO}_{2}$ and without disruption of the underlying forests. Thoughts are put forth on how to redesign landfills to achieve secure permanent biomass sequestration.

The cost of Carbon Capture, Use, and Storage (CCUS) is calculated to be about $\$ 190 / \mathrm{mt} \mathrm{CO}_{2}$ for an SRM hydrogen plant. The cost of CCUS for growing switchgrass and burial in modified landfills is calculated to be about $\$ 120 / \mathrm{mt} \mathrm{CO}_{2}$ for a conservative yield of 3.5 tons/acre switchgrass. Development of high yield switchgrass $(6 \mathrm{mt} / \mathrm{acre})$ could lower that cost to about $\$ 88 / \mathrm{mt} \mathrm{CO}_{2}$. Thus, growing and sequestering switchgrass would be a low-cost Direct $\mathrm{CO}_{2}$ Capture option.

\section{ACKNOWLEDGMENTS}

Amelse received a Ph.D in Chemical Engineering from Northwestern University, Evanston, IL USA. He worked for Amoco Chemical Company R\&D (now BP Amoco Chemical Company Petrochemicals Technology, Naperville, IL USA, for 35 years, mainly on paraxylene catalyst and process technology. He retired in April 2017 and joined CICECO, Aveiro Institute of Materials, Department of Chemistry, University of Aveiro, Portugal as Invited Principal Investigator to continue collaborating with Dr. Luis Mafra on the characterization of molecular sieve catalysts and adsorbents via Solid State NMR, work started while he was at BP. He has published numerous papers and is co-inventor on 17 issued or pending patents. He was recently extended a 3-year unpaid position as Invited Associate Professor, so he can continue to teach on-line and collaborate on several projects following his return to the U.S.

Paul Behrens received a Ph.D. in Chemical Engineering from the University of Delaware. He joined Amoco Chemical Company R\&D and spent 28 years there, supporting a number of chemical processes, including para-xylene, PTA, polybutene, 2,6-naphthalene dicarboxylic acid, and efforts to commercialize cellulosic bioethanol. He continues as an independent consultant with expertise in process modeling, design, and economics. Since his semi-retirement, he purchased a farm near Indianapolis, IN where he grows hay.

This article was developed as an independent contribution. As such, the authors declare no organizational funding for this article.

\section{REFERENCES}

[1] R. Lindsey, R. (2020) "Climate Change: Atmospheric Carbon Dioxide," Climate.gov, 2020.

https://www.climate.gov/news-features/understanding-climate/climatechange-atmospheric-carbon-dioxide

[2] Amelse, J. Towards Achieving Net Zero Carbon Dioxide by Sequestering Biomass Carbon. Preprints 2020, 2020070576 (doi: 10.20944/preprints202007.0576.v4)

[3] Climeworks, https://www.climeworks.com. Accessed May 18, 2021.

[4] Carbon Engineering, "Direct Air Capture of $\mathrm{CO}_{2}$," https://carbonengineering.com Accessed May 18, 2021.

[5] CNBC, "Money Is Pouring Into Carbon Capture Tech, But Challenges Remain,"

https://www.bing.com/videos/search?q=youtube+direct+carbon+capture $\&$ docid $=608030492884406195 \& \mathrm{mid}=0 \mathrm{~F} 93037 \mathrm{E} 0 \mathrm{~B} 22 \mathrm{DB} 3462310 \mathrm{~F} 9303$ 7E0B22DB346231\&view=detail\&FORM=VIRE Accessed May 18, 2021.

[6] IEA, "Building the Cost Curves for CO2 Storage: North America," Report 2005/3, 2005.

[7] K. Painter, "Costs of Harvesting Hay: Does it Pay to Put Up Your Own," https://www.progressivecattle.com/topics/facilitiesequipment/costs-of-harvesting-hay-does-it-pay-to-put-up-your-own Accessed May 18, 2021.

[8] US Energy Information Authority (EIA), “Annual Energy Review," 2020. https://www.eia.gov/totalenergy/data/annual/

[9] BP, "Statistical Review of World Energy 2020: $69^{\text {th }}$ Edition, 2020. https://www.bp.com/content/dam/bp/businesssites/en/global/corporate/pdfs/energy-economics/statistical-review/bpstats-review-2020-full-report.pdf

[10] EIA, "Energy Facts Explained," 2017. Current version at: https://www.eia.gov/energyexplained/us-energy-facts/

[11] EIA, “Annual Energy Outlook 2020," https://www.eia.gov/outlooks/aeo/ Accessed Sept 9, 2020.

[12] EIA, "Petroleum and Other Liquids,"

https://www.eia.gov/international/data/world/petroleum-and-otherliquids/more-petroleum-and-other-liquids-

data?pd $=5 \& \mathrm{p}=000 \mathrm{gfs} 1001 \mathrm{vg} 00000000080004000001 \mathrm{o} 0 \mathrm{vg} 0000000000 \mathrm{~g}$ $000000000001 \mathrm{~g} \& \mathrm{u}=0 \& \mathrm{f}=\mathrm{A} \& \mathrm{v}=$ mapbubble \& $\mathrm{a}=-$

$\& \mathrm{i}=$ none $\& v \mathrm{v}=$ value $\& \mathrm{t}=\mathrm{C} \& \mathrm{~g}=0000000000000000000000000000000000$ $0000000000000001 \& 1=249$ -

ruvvvvvfvtvnvv1vrvvvvfvvvvvvfvvvou20evvvvvvvvvvvnvvvs0008\&s=$662688000000 \& \mathrm{e}=1609459200000 \&$ Accessed May 18,2021

[13] EIA, "U.S. Sales of Distillate Fuel Oil by End Use," http://www.eia.gov/dnav/pet/pet_cons_821dst_dcu_nus_a.htm Accessed May 18, 2021.

[14] USDA, "Feed Grains Data: Yearbook Tables," 2020. https://www.ers.usda.gov/data-products/feed-grains-database/feedgrains-yearbook-tables.aspx 
[15] Sandia Labs News Release, "Biofuels can provide viable, sustainable solution to reducing petroleum dependence, say Sandia researchers," 2009. https://share-ng.sandia.gov/news/resources/news releases/biofuels-canprovide-viable-sustainable-solution-to-reducing-petroleum-dependencesay-sandia-researchers/ Accessed May 19, 2020.

[16] S. Retka Schill," "Zero to 10 Million in 5 Years, Ethanol Producer Magazine, June 26, 2018.

[17] EIA, "Monthly Biodiesel Production Report," https://www.eia.gov/biofuels/biodiesel/production/ Accessed May 18, 2021.

[18] US Department of Agriculture (USDA), "US Bioenergy Statistics," https://www.ers.usda.gov/data-products/us-bioenergy-statistics/

[19] USAfacts.org, "How many electric cars are on the road in the United States?,"

https://usafacts.org/articles/how-many-electric-cars-in-united-states/ Accessed May 18, 2021.

[20] J. A. Bassham, "Photosynthesis," Encyclopaedia Britannica, 2020.

[21] J. Carson, J., "How Much Carbon Can Soil Store | Fact Sheets |," 2020. http://www.soilquality.org.au/factsheets/how-much-carbon-can-soilstore Accessed May 25, 2020.

[22] EPA, "Facts and Figures about Materials, Waste and Recycling," 2020. https://www.epa.gov/facts-and-figures-about-materials-waste-andrecycling/national-overview-facts-and-figures-materials\#Landfilling Accessed May 22, 2020.

[23] E.G. McPherson, N.S. van Doorn, and P.J. Peper, US Forest Service General Tech. Report PSW-GTR-253, 2016.

[24] T. Crowther, H. Glick, K., Covey, K. et al., "Mapping tree density at a global scale," Nature, 525, 201-205, 2015.

[25] GreenBlizzard, "How Many Trees in the US ?," 2016. http://greenblizzard.com/2015/09/28/how-many-trees-in-the-u-s/ Accessed May 22, 2020.

[26] Agency for Toxic Substances and Disease Registry, "Landfill Gas Primer - An Overview for Environmental Health Professionals, Chapter 2: Landfill Gas Basics," 2001. https://www.atsdr.cdc.gov/HAC/landfill/html/ch2.html

[27] S. Datta and L. Eastes, Biodegradation in Municipal Solid Waste Landfills, Geoenvironmental Engineering, 2015.

https://www.geoengineer.org/education/web-class-projects/cee-549geoenvironmental-engineering-fall-2015/assignments/biodegradation-inmunicipal-solid-waste-landfills Accessed August 2, 2020.

[28] National Council for Air and Stream Improvement, "Critical review of forest products decomposition in municipal solid waste landfills," Tech. Bulletin 872, 2004.

[29] Y. Chen, J.J. Cheng, K.S. Cramer, "Inhibittion of anaerobic digestion process: A review," Biosource Tech., 99, 4044-4064.

[30] G. Coskuner, M. S Jassim , N. Nazeer, and G. H Damindra, "Quantification of landfill gas generation and renewable energy potential in arid countries: Case study of Bahrain, Waste Management \& Research, vol. 38, 10: pp. 1110-1118.

[31] Alexander A, Burklin C and Singleton A (2005) Landfill Gas Emissions Model (LandGEM) Version 3.02 User's Guide. Washington, DC: U.S. Environmental Protection Agency Office of Research and Development.

[32] IEA, "The Future of Hydrogen - Report Prepared for the G20, Japan," 2019.

[33] IEA, IEAGHG Technical Review 2017-TR3, Reference Data and Supporting Literature Reviews for SMR Based Hydrogen Production with CCS, 2017.

[34] Farm-Energy, "The Economics of Switchgrass for Biofuels," 2019. https://farm-energy.extension.org/the-economics-of-switchgrass-forbiofuel/

[35] A. Bagchi, Design of Landfills and Integrated Solid Waste Management, $3^{\text {rd }}$ Edition, John Wiley \& Sons, Inc., 2004. ISBN 0-471-25499-1

[36] DairyNZ, "Density and Storage of Feeds," https://www.dairynz.co.nz/feed/supplements/density-and-storage-offeeds/\#: :text $=\% 20 \% 20 \% 20 \% 20$ Silage $\% 20$ types $\% 20 \% 20, \% 20 \% 2015$ $20 \% 20 \% 204 \% 20$ more $\% 20$ rows $\% 20$

[37] USDA, "Feedgrains Sector at a Glance." USDA ERS - Feedgrains Sector at a Glance Accessed May 23, 2021.

[38] USDA, "Related Data \& Statistics," USDA ERS - Related Data \& Statistics. Accessed May 23, 2021.

[39] USDA, "Land Use: Range and Patture," Range \& Pasture | NRCS (usda.gov). Accessed May 23, 2021. 